MARTA VREMIR

\title{
ÎN FAȚA CIRESULUI. DENUMIRI DE CULORI ÎN LEXICONUL DE LA BUDA (1825)
}

1. Realitatea oferă o varietate aproape infinită de culori și nuanțe pe care vorbitorii o exprimă, de asemenea, la fel de variat și complex. Numele de culori în limba română au făcut obiectul de cercetare al mai multor studii, majoritatea concentrându-se pe aspectele de ordin lexico-semantic. Se poate observa o oarecare incongruență la nivelul cantitativ al unor culori, aceasta datorându-se unor factori extralingvistici, pe de o parte (afectivi, perceptivi), dar și lingvistici (evoluția diacronică a unei limbi). Lucrarea de față își propune să inventarieze denumirile cromatice (cromonimele) extrase din Lexiconul de la Buda1; în acest sens, mă voi concentra, în primul rând, asupra culorilor de bază, parcurgând termenii fundamentali ai paradigmelor cromatice; totodată, îmi propun să prezint culorile derivate care se regăsesc în baza de date.

Culorile sunt o parte inevitabilă a modului în care percepem lumea. Gândim în și cu culori, acestea ne marchează existența emoțională și socială. Culorile ne ajută, oarecum, să delimităm spațiul fizic, iar stările noastre sufletești sunt și ele descrise în culori: vedem roșu în fața ochilor, ne înnegrim de furie, suntem verzi de invidie. Știm bine că ele sunt acolo, omniprezente, reprezentând o proprietate inalienabilă a tuturor obiectelor din lumea noastră.

Știinţific vorbind, termenii care definesc culorile se referă la aspectul cromatic al lucrurilor așa cum sunt ele văzute în lumina soarelui. Se numește culoare percepția de către ochi a uneia sau a mai multor frecvențe de lumină. În cazul oamenilor, această percepție provine din abilitatea ochiului de a distinge câteva (de obicei trei) analize filtrate diferite ale aceleiași imagini. Percepția culorii este influențată de biologie (de ex. unii oameni se nasc văzând culorile diferit, alții nu le percep deloc, de ex. daltoniștii), de evoluția aceluiași observator, și de culorile aflate in imediata apropiere a celei percepute (aceasta fiind explicatia multor iluzii optice). Ochiul nu distinge, ca având culori diferite, orice surse luminoase cu distribuții spectrale diferite. Percepția culorilor de către ochi - de fapt, de către creier - este complicată de faptul că analizatorul vizual compară culoarea luminii reflectate de un obiect cu culorile luminii din mediu.

Termenul culoare este definit în DEX la sensul de bază drept ,însușire a luminii determinată de compoziția sa spectrală, care permite ochiului să perceapă în mod diferit radiațiile vizibile incidente pe retină, având aceeași intensitate, dar lungimi de undă diferite”; culoarea este „o proprietate a corpurilor de a absorbi

\footnotetext{
${ }^{1}$ Lexiconul de la Buda (1825), ediție electronică realizată de Maria Aldea, Daniel-Corneliu Leucuța, Lilla Marta Vremir, Vasilica Eugenia Cristea, Adrian Aurel Podaru, coordonator Maria Aldea, ClujNapoca, 2013: https://www.bcucluj.ro/lexiconuldelabuda/site/login.php.
} 
inegal diferitele componente monocromatice ale luminii, modificând astfel compoziția luminii împrăștiate sau transmise de ele; respectiv, se definește ca aspectul colorat al corpurilor".

Culorile fundamentale sunt definite ca fiecare dintre culorile (roșu, galben și albastru) care nu pot fi obținute prin amestecul altor culori, dar care, amestecate între ele, dau toate celelalte nuanțe și culori.

Deși acceptat în terminologia de specialitate ale artelor plastice, DEX nu înregistrează termenul de non-culoare (albul, negrul și toată gama griurilor pe care o poate forma amestecul celor două culori sunt clasificate ca și non-culori).

Din punct de vedere etimologic, patru dintre culorile fundamentale sunt moștenite din latină (albastru, galben, roșu și verde). Acestea (în afară de verde) sunt cuvinte cu o mare frecvență în limbă, baze generatoare de numeroase creații interne (derivate, compuse etc.), fiind componentele multor unități frazeologice (Moroianu 2011, p. 223). În aceeași situație se află și alb și negru (de asemenea, moștenite din latină).

Noțiunea culorii într-o limbă se construiește, de regulă, pe baza unor imagini concrete (Chirilă 2018, p. 58). În limba română modernă, varietatea nuanțelor se exprimă, de obicei, analitic, cu ajutorul unor structuri sintagmatice care cuprind termenul bază și o serie de adjective (închis, deschis, aprins etc.) sau de substantive ce reprezintă obiectul comparat (Popescu 2014, p. 265). Denumirile culorilor alcătuiesc în fiecare limbă un sistem complex, care este în perpetuă modificare, numărul de culori derivate, respectiv de nuanțe cromatice crescând odată cu evoluția civilizației, constituind un câmp semantic conturat, dar flexibil (Codreanu, Stanțieru 2017, p. 36).

Cum cromaticul este strâns legat de realitatea concretă, termenii care denumesc numele de culori formează un câmp lexico-semantic bogat și variat.

Sistemul lexico-semantic al numelor de culoare în limba română este unul extrem de complex (Bidu-Vrânceanu 1976, citat în Stanțieru, Bârsanu 2015, p. 37). În limba română modernă, lista nuanțelor cromatice este foarte bogată, cu toate că au la dispozitiie, pentru a le clasa lingvistic, un stoc de cuvinte mici (cum sunt: roșu, verde, negru etc.), la care se adaugă termenii cu rezonanță metaforică (vișiniu, cărămiziu, ruginiu, cafeniu etc.) (Stanțieru, Bârsanu 2015, p. 37)

În bibliografia de specialitate, termenul de 'culoare primară/fundamentală' se referă, de regulă, la culorile: alb, negru, verde, albastru, galben, roșu; acești termeni având la bază nume de culori moștenite din latină; sunt numite și culori-prototip, culori de bază (Stanțieru, Bârsanu 2015, p. 37). Sunt considerate termeni fundamentali ai paradigmelor cromatice (cuvinte-axiomă), în sensul că toate celelalte unități lexicale care exprimă ideea de culoare se raportează din punct de vedere semantic, în primul rând, la acestea.

Lexiconul de la Buda (Lesicon românescu-latinescu-ungurescu-nemtescu, Budæ, Typis et Sumtibus Typographiæ Regiæ Universitatis Hungaricæ, 1825) este cea mai amplă şi mai importantă lucrare apărută în acea perioadă în ediţia Tipografiei Universității Regale a Ungariei din Buda. Materialul lingvistic al Lexiconului de la Buda prezintă realitatea lingvistică din perioada (îndelungată) de elaborare a dicţionarului pe mai multe nivele şi pe multiple registre. Dicţionarul cvadrilingv fiind, totodată, şi un dicționar explicativ - este o lucrare normativă care s-a dorit a 
fi de largă circulaţie, contribuind, astfel, la accentuarea conştiinţei etnice, la evidenţierea propriei identităţi naţionale.

Prezenta lucrare abordează terminologia referitoare la denumirile de culori.

2. În total, am identificat în Lexiconul de la Buda 215 termeni cromatici (nume de culori, referințe coloristice, parafraze care au în conținut diferite culori etc.) În ceea ce urmează, voi prezenta culorile ce se regăsesc în corpul LB.

2.1. Notiuni de cromatică prezente în LB:

Termenul culoare, ca atare, este sporadic în masa lexicală a românei din LB, varianta morfologică (s.n.), deopotrivă cu adaptarea stângace a cuvântului la necesitătile fonologice ale românei denotă caracterul lui exotic. Noțiunea se regăsește, lexical, prin cuvântul pe care-l folosim azi, preponderent în segmentele de text în latină, în parafrazele (color, color clavus, colore murino, aurei coloris, etc.). Termenul românesc care denotă în LB noțiunea de 'culoare' este FAṬĂ.

[Color] Cadavros, cu color [...] de trup mort, de mortăciune: cadaverosus: [...] holt színü: totenfärbig.

Coloru[1] seminței de cafea e sein cam vânăt: cinereus nigrescens.

Color roșu: color ruber: veres szín: die rote Farbe.

Pentru noțiunea față, DEX are definiția, la sensul II. 4., de 'culoare'. În corpul cuvântului se dă exemplul: A-i ieși (unei pânze, unei stofe) fața (la soare, la spălat etc.) = a se decolora. În LB, regăsim următoarea definiție:

Față, văpseală: color: szín: die Farbe. p.e., fața trandafirului: color roseus: ró[z]saszín: die Rosenfarbe; această pănură își ține fața: hic pannus retinet colorem: ez a posztó megtart[j]a a színét: dieses Tuch behält die Farbe.

Câteva exemple pentru culori exprimate prin această formulare:

ca auru sau în fața aurului; sur, în faţa brumei; în fața cenușei; în faţa cireșului; în fața fierului; în fața nucului; în fața oleiului; în fața porumbului; față roșie; în fața focului; în fața şofranului; în fața şoarecelui; în fața știucii; în fața apei, dela venetus; în fața vioalei.

\subsection{Noțiuni de închis/deschis/colorat:}

Conform DEX, 'închis' are următoarea definiție: (Despre culori) Situat, în gama culorilor, mai aproape de negru decât de alb. 'Deschis': (Despre culori) Cu nuanță mai apropiată de alb decât de negru; pal, luminos, clar. 'Colorat': Care are o anumită culoare (alta decât cea albă sau neagră); care are mai multe culori [multicolor].

În LB găsim următoarele definiții: Inchis:

Bălțat, închis, întunecat: ravus: setét színü: grau, dunkelfärbig.

Închis, despre văpsele: fuscus: setét: dunkel, dunkelfarbig.

Deschis:

Deschis despre vreo văpseală care trage cam albă: candicans: világos: hell. $p$. e. vânăt deschis: candicans e caeruleo: világos: hellblau. 
Colorat:

Cacior, pistriț, vărgat, pătat, picat cu alt color: varius, variegatus, scutulatus, maculosus, sparsus: babos, iromha, tarka, pettegetett: scheckig, gesprenkelt, gefleckt.

Florilat: albo sparsus: romha, pettegetett, tarka: weißgefleckt, weißgesprenkelt, weißsprenkelig [sensul 'colorat' corespunde, în acest caz, echivalentului din segmentul de text în maghiară tarka 'colorat'].

Împistrit: maculosus, varius: tarka: scheckig, bunt gefleckt.

Împistritură: varietas: tarkaság: das Bunte, die Mannigfaltigkeit der Farben.

Împistresc: vario, vermiculor, variego, maculo: tarkázni, tarkán festeni: scheckenbunt, oder schecktig machen.

Oacăr, pestriţ pre obraz: varius, maculosus in facie: tarka, pettegetett ábrázat: bunt, gefleckt im Gesicht.

Pestriț: varius, variegatus, scutulatus, maculosus, sparsus: tarka, iromha, pettegetett, kendermagos: scheckig, bunt, gesprenkelt, weißgefleckt (și Pistriț).

Tărcat: varius, versicolor, maculosus, scutulatus: tarka: bunt, scheckig.

Tărcătură: varietas: tarkaság: das Bunte, das scheckige Wesen, die Manigfaltigkeit der Farben.

Tigridu, sau tărcat ca tigridul.

Tarce: equus maculosus: tarka ló: der Schecke, ein scheckiges Pferd.

\section{Culorile fundamentale în Lexiconul de la Buda}

În câmpul lexico-semantic românesc al culorilor, termenii moşteniţi din latină (alb, negru, verde, roşu, galben, albastru, vânăt) ocupă o poziție privilegiată.

\subsection{Alb}

Culoarea albă este definită în DEX astfel: adj. Care are culoarea zăpezii, a laptelui; (despre culori) ca zăpada, ca laptele. subst. (o descriere din perspectivă științifică; această metodă se repetă, de altfel, și la descrierea altor culori fundamentale) Culoare obținută prin suprapunerea tuturor componentelor spectrului luminii zilei; culoarea descrisă mai sus (descrierea fizică a fenomenului este completată de trimiterea la definiția dată adjectivului). În alte dicționare, mai vechi (vezi LM, RES, etc. cf. Baltă 2010), adjectivul alb este echivalat cu parafraza 'de culoare albă', ajungând la procedeul circularității lexicografice, definiţia adjectivului fiind 'care are culoarea albă'. Având în vedere că LB nu este un dicționar explicativ, se dau doar echivalentele: albus, candidus; fejér; weiß.

\section{Adjectiv:}

Albastru - adecă ori din ce față trăgând spre alb: candicans: fejéres: weißlich, hell, licht.

Albeneț: subalbus, subalbidus, subalbicans: fejéres: weißlich.

Albeț v. Albeneț.

Albit - înălbit: albatus, dealbatus: fejérített, kifejérített: weiß gemacht.

Albiu v. Albeneț.

Alburiu v. Albeneț.

Albuț v. Albeneț.

Cărunt: canus: ősz: grau. Ital. canuto. 
Nălbastru - Albastru.

Nălbit 1) pânză, ață etc.: insolatus: fejérített: gebleicht. 2) casă, i. e. văruită: trulissatus: kimeszelt: ausgeweißt.

Nealbit p. e., pânză: haud insolatus: fejérítetlen: ungebleicht.

Plăviț a) i. e. albeneț: subalbus, subalbidus, subalbicans: fejéres, fejér szabású: weißlich.

\section{Substantiv:}

Albeală: cerusa alba: fejérítö: die Bleiche, der Bleiweiß.

Albeață, orice formă sau figură albă: album, albedo, albugo, albitudo: fejérség: das Weiße.

Albire, înălbire: albatio, dealbatio: fejérítés, kifejérités: das Bleichen, das Weißen, die Ausweißung.

Nălbire 1) de pânză: insolatio: fejérítés: die Bleiche, das Bleichen. 2) în casă: trulissatio: meszelés: das Ausweißen, die Ausweißung.

Nălbitoare 1) muiere carea nălbește pânză: insolans: fejérítö: die Bleicherin. 2) i.e. loc de nălbit pânză: locus in solandis linteis: vászonfejérítő hely: die Leinwandbleiche, der Bleichplatz.

Nălbit - nălbire.

Nălbitură - nălbire.

Verb:

Albesc: fejéredni - I. neutr. adecă mă fac alb: albesco: fejéredni: weiß werden. II. Act. fac ceva alb, înălbesc: albo, inalbo, dealbo: fejéríteni: weissen, weiß machen. $-p . e$., pânză, ață, lumini de ceară: insolo: fejéríteni: bleichen - casa, adecă văruiesc: dealbo, trulisso: kifejéríteni, meszelni: weissen, ausweißen.

Cărunțesc: canesco: öszülni, megöszülni: grauen, grau werden.

Încărunțesc v. Cărunțesc.

Nălbesc 1) i. e. fac ceva alb: albo, inalbo, dealbo: fejérítem: weißen, weiß machen. 2) pânză, ață, lumini de ceară: insolo: fejéríteni: bleichen. 3) casa, i. e. văruiesc: dealbo, trulisso: kifejéríteni, meszelni: weißen, ausweißen.

Adverb:

Alb: albe, candide: fejéren: weiß.

Alb în combinații lexicale:

Comparații:

ca lebăda, adecă foarte alb: fejér, mint a hattyú: schneeweiß.

ca neaoa, foarte alb: niveus: fejér, mint a hó: schneeweiß.

alb ca zăpada: fejér, mint a hó: weiß wie Schnee, schneeweiß.

Alb în denumiri de plante:

Brad alb 1. - Molid - silhă: lucfa, fejérfenyő. 2. Pinus picea Linn., Abies alba vel candida: fejérfenyő: die Weißfichte, Weißtanne.

Cocăză 1. albă, adecă agriși: Ribes grossularia, Linn.: köszméte, pöszméte, csipkeszölő, egres: die Stachelbeere. 2. coacăză-albă: Ribes grossularia, Linn.: köszméte, pöszméte, csipkeszőlő, egres: die Stachelbeere.

Crin-alb: Lilium candidum, Linn.: fejér liliom: die weiße Lilie.

Ferecea-albă - o plantă: Spiraea filipendula, Linn.: varjúmogyoró: das rote Steinbrech.

Lilie albă: Lilium candidum, Linn.: fejér liliom: die weiße Lilie. 
Molid, silhă, brad-alb: Pinus sylvestris, Abies candida: lucfa, fejérfenyő: die Weißfichte, Weißtanne, der Kienbaum, Kiefer, die Fohre.

Nalbă albă (mare): Althaea officinalis, Linn.: mazola: die Althee, der Eibisch, oder Ibisch.

Năprasnic - o floare albă: Clematis erecta, Linn.: palackfü: das Brennkraut.

Pelin alb: fejér üröm (Artemisia absinthium).

Pin $i$. e. brad-alb, molit: Pinus sylverstris, Abies candida: lucfa, fejérfenyő: die Weißfichte, Weißtanne, der Kienbaum, Kiefer, die Fohre.

Plopu alb: Populus alba, Linn.: fejér nyárfa: die Weißpappel.

Plumână albă: Nymphaea alba, Linn.: fejér vízitök: die weiße Seerose, die Wassertulpe.

Răchită albă: Salix viminalis Linn.: rekettye, rekettyefüz, kenderfüz, rakattya: die Ufer-, Seil-, Korb-, Haar-, Fischerweide.

Sfeclă albă: fejér cékla.

Trandafir alb: Rosa alba: fejér kerti rózsa: die weise Gartenrose.

Trifoiu-alb: Trifolium repens, Linn.: fejér lóhere: der Bienenklee, Honigklee, der kleine weiße Wiesenklee.

Alb în denumiri de animale:

Haringă sau Harengu sau Hăreng - un pește mic alb carele nu se află numai în Marea Septemtrionului (de la mezul-nopței) și se chiamă și halec: Clupea harengus, alec, halex, Thrissa borealis, thetta, Alosa minor: hering: der Häring, Hering.

Peșce alb: Cyprinus alburnus: fejér keszeg, fejérhal: der Weißfisch.

Alte combinații:

Albeața unghiei.

Albuș 1) a ochiului: albugo oculi: szem fejére: das Weiße im Augen. 2) a oului: album vel albumen ovi: tojás fejére: das Weiße im Ei, oder das Eiweiß.

Habă - pănură albă.

Humă - spoială, pământ alb.

Humă - pământ alb.2

Nădragi albi prostești.

Marmore alb.

Mâzgă 1) umezala cea albă supt scoarţa lemnului.

Miere-de-trestie. a) albă.

Pănură albă.

\subsection{Negru}

Culoarea neagră este definită în DEX, ca adj., astfel: (despre obiecte, ființe etc.) Care nu reflectă lumina (se precizează lipsa culorii, a luminii), care are culoarea cea mai închisă (se indică tipul culorii); de culoarea funinginii, a cărbunelui (indicarea unor referenți); (despre culori) ca funinginea, ca penele corbului (utili-

\footnotetext{
${ }^{2}$ Principiile de organizare ale materialului lexical în LB (a) diferă substanțial de tradițiile de aliniere semasiologică moderne, care aplică pentru lemare principiul etimologic, pe cel gramatical sau o combinație a celor două și (b) sunt, prin felul în care a fost adunat materialul în decursul a trei decenii, eterogene. De aceea, acolo unde aici consemnarea vocilor pare redundantă, ea reflectă lista de cuvinte-titlu din LB.
} 
zarea unor comparații pentru indicarea sensului); cu cea mai închisă nuanță. Ca subst.: Materie colorantă de culoare neagră (vezi principiul circularității lexicografice!); vopsea neagră.

In LB, apar următoarele referințe la culoarea neagră:

Adjectiv:

Negricios: nigricans, nigellus, subniger: feketés, feketécske: schwärzlich, etwas schwarz.

Negriu - Negricios.

Negru: niger, ater, fuscus, pullus: fekete: schwarz.

Negruș: nigellus, subniger: feketés, feketécske: schwärzlich, etwas schwarz.

Negruț: nigellus, subniger: feketés, feketécske: schwärzlich, etwas schwarz.

Oacheș a) i. e. negru la sprâncene: nigris superciliis: fekete szemöldökü: mit schwarzen Augenbraunen. b) i. e. cu ochi negrii: nigris oculis: feketeszemü: schwarzäugig. c) i. e. bârnaciu, negriu la față: badius, spadix, subfuscus: barnaképü: braun, braunt.

Ocheșel dim.

Substantiv:

Cerneală tintă, Negreală: subst. atramentum.

Cerneală de cernit: feketítő: die Schwärze.

Cernitor: infector colore atro: feketítő: der Schwarzfärber.

Negreală: atramentum: feketítő: die Schwärze.

Negreață: nigredo, nigritia: feketeség: die Schwärze, eine schwarze Gestalt.

Negrime: nigror, nigredo, nigritudo: feketeség: die Schwärze.

Verb:

Cernesc: nigro atro colore inficio: feketíteni: schwärzen, schwarz färben.

Înnegresc I. verb. act. ceva: 1) i. e. fac negru: nigro, denigro, nigrifico, fusco, nigrum vel atrum reddo: feketíteni: schwärzen, schwarz machen. II. rec. mă înnegresc: 1) i. e. mă fac negru: nigresco: megfeketedni, megfeketülni: schwarz werden.

Negresc I. verb. act. 1) fac ceva negru: nigro, denigro, nigrum, atrum reddo: feketíteni: schwärzen, schwarz machen. II. neutr. i. e. mă fac negru: nigresco: feketülni, megfeketedni: schwarz werden.

Negru în combinații lexicale:

Comparații:

Rășină - negru ca rășina: piceus, picinus: fekete, mint a szurok: pechschwarz.

Negru în denumiri de plante:

Chimin negru: Nigella sativa, Linn.: fekete kömény: die Nigelle, der schwarze Kümmel, der schwarze Koriander, der Nordensamen, Spargensamen.

Iarbă-neagră, urzică-neagră: Scrophularia nodosa Linn.: feketecsalány: die Knotenwurz.

Mălin negru: Ligustrum vulgare Linn.: fagyalfa: das Mundholz, die Rainweide.

Pelin negru: fekete üröm (Artemisia vulgaris).

Pelin-negru: Artemisia vulgaris, Linn.: fekete üröm, tapló üröm: der gemeine oder schwarze Wermut, der Beifuß.

Plop-negru: Populus nigra, Linn.: jegenyefa: die Schwarzpappel, oder die Pappelweide. 
Rapiță neagră: Sinapis nigra, Linn.: mustárrepce: der schwarze Senf.

Strugurei negríi: Ribes nigrum: feketeribizli: die schwarze Johannisbeerchen, die Bocks- oder Gichtbeeren.

Urzică neagră, adecă o plantă neagră: Scrophularia nodosa, Linn.: fekete csalány: die Knotenwurz.

\section{Alte combinații:}

Mare neagră.

s.v. Stau - ţie îți stau bine veștmintele negre: vestes nigrae tibi recte quadrant: néked jó[1] áll a fekete öltözet: dir stehen die schwarzen Kleider gut an.

\subsection{Roșu}

Culoarea roșie este definită în DEX astfel: adj. 1. De culoarea sângelui (definiție prin indicarea obiectului-tip); 2. Roșcat, roșcovan, arămiu (definiție prin sinonimie); 3. De culoare rumenă aprinsă (prin indicarea nuanţei unei alte culori); 4 . (despre metale) Înroșit în foc; incandescent. Ca subst.: Una dintre culorile fundamentale ale spectrului luminii, situată în marginea acestuia dinspre lungimile de undă mari; culoarea sângelui.

Culoarea roșie în LB apare în următoarele situații:

\section{Adjectiv:}

Cireș - în fața cireșului: cerasinus: cseresnyefa színủ: kirschfarbig.

Sânge - în fața sângelui sau roșu ca sângele: sanguineus: vérszínü: blutfarbig, blutfärbig, blutrot.

Năsădit: nigricans e rubro: setétpiros: dunkelrot [**Năsădit indică, de fapt, două culori: violaceu (violaceus: violaszínü: veilchenblau), respectiv roșu închis, vezi și la albastru].

Mohorât: coccineus: skárlátszínủ: scharlachfarben, scharlachrot.

Roșcoban: genis rubris, facie rubra: piros arcú: rotbäckig.

Roșcovan v. Roșcoban.

Roșiatec: rubidus, rubicundus, subruber, subrufus, subrubicundus: vereses, veresellő: rötlich, etwas rot.

Roșietec-Roșiatec.

Roșior: rubellus, rubellulus, rus[s]eolus. rubicundulus: veresecske, pirosacska: etwas rötlich. sau $v[$ ide] roșetec.

Roșu 1) ruber, rubrus, rutilus, russus. veres, piros: rot. - la păr: rufus: vereshajú: rotköpfig, rothaarig, vel subst. der Rotkopf. - Marea Roșie: Mare Rubrum: Verestenger: das rote Meer. - ou roșu: ovum rubrum: pirostojás: ein rotes Ei. -2) color roșu: color ruber: veres szín: die rote Farbe.

Roșuț v. Roșior.

Roṣ v. Roșu.

Rumean: rubicundus, rubris genis: piros, piros arcú: rot, rotbäckig.

Rumenel: rubicundulus: pirosocska: rötlich.

În fața trandafirului: adj. roseus: ró[z]saszínü: rosenfarben, rosenrot.

\section{Substantiv:}

Carmin: carminum: karmin: der Carmin.

Chinovar - ținabor: cinnaboris: cinabor: der Zinnober. 
Mohorâciune: coccum, coccinum: skárlát: der Scharlach.

Porfiră, purpură, vison: purpura: veres bársonyöltözet: der Purpur.

Roșală: rubrica, color ruber: veres festék: der Rötel, oder Rötelstein, die rote Farbe.

Rușață 1) roșeală: rubor, rubedo: veresség, pirosság: die Röte. 2) orbanţ: erysipelas, gutta rosacea: orbánc, hagymázszeplő: der Rotlauf, die Rose.

Roșele - Roșală.

Rumeneală, cea firească care este, p. e., în vântul căruiva: rubor, rubedo: pirosság: die Röte.

Rumeneală, cu care se sulimănește cineva: pigmentum rubrum, rubrica, piros kendőző, orcafestő: die rote Schminke.

Rușuliță - Roșioară.

Rușală - Roșială - Roșu.

Rușeață sau roșeață 1. roșeală: veresség, pirosság; 2 . orbanț orbánc.

\section{Verb:}

Roșesc I. verb. act. ceva: rubefacio, rubrum reddo: veresíteni, veresen, pirosan csinálni: röten, rot machen. II. neutr. sau mă roșesc: 1) i. e. mă fac roșu: rubesco: veresedni, pirosodni: rot werden. 2) de rușine: rubeo, erubesco: pirulni, megpirulni: erröten.

Rumenesc: piros, veres kendözövel kenni: rotschminken.

Rumenesc: rubrica tingo, fuco, infuco: piros, veres kendőzővel kenni: rotschminken.

Rușesc - Roșesc.

Roșu în combinații lexicale:

Comparații:

Roșu ca focu sau în fața focului: ignitus, ignicolorus: tüzes: feurig, feuerrot.

In denumirile de plante:

Brad roșu: larix: veresfenyő: der Lerchenbaum.

Busuioc-roșu, v. Busuioc-de-câmp (Prunella vulgaris, Linn.: gyékfü: die Prunelle.)

Cocăză roșie, adecă strugurei: Ribes rubrum, Linn.: veresszőlő, tengeriszőlö, ribizli: die Ribisel, das Weinbeerchen, die rote Johannisbeer.

Crin-roșu: Lilium bulbiferum, Linn.: tüzes liliom: die Feuer - Lilie.

Iarbă-roșie: Thlaspis arvense, Linn.: nyénfü: der Bauernsenf, das Heidenreich.

Lilie roșie: Lilium bulbiferum, Linn.: tüzesliliom: die Feuerlilie.

Melin roșu - adecă scumpie, liliac v. Iorgovan (scrinte, scumpie, melin: Orgonosa vel Syringa vulgaris: szelence, borostyán: der spanische Holunder).

Răchită roșie: Salix purpurea, Linn.: csigolyafa: die Bandweide, Rotweide.

Roșioară, filimină: Calendula officinalis, Linn.: tủzvirág, perennis[z]: die große Ringelblume.

Scânteuță-roșie: Anagallis arvensis, Linn.: tyúkszemfü: der Ackergauchheil, der rote Hühnerdarm, der Hühnertritt.

Sfeclă roșie: beta rubra vel beta vulgaris: cékla, veresrépa: die rote Rübe.

Strugurei roșii: Ribes rubrum, Linn.: veresszőlő, tengeriszőlő, ribizli: die rote Johannisbeere, die Ribiseln, Weinbeerchen.

Știr roșu: Amarant[h]us sanguineus, Linn.: veresparéj: der rote Meieramarant.

Trandafiru roșu: Rosa centifolia: piros kerti rózsa: die Rose.

Trifoiu roșu: piros lóhere (Trifolium pratense). 
**[Potroacă - o iarbă sau plantă, care se face in iulie, cu flori tufoase roșii; ferea-pământului, țentaurea, iarbă de friguri: Gentiana centaurium minus, Linn. febrifugia, Apul.: ezerjófü, földepe-fü, cintorja: die Erdgalle, das Fieberkraut, Tausendguldenkraut].

Alte combinații:

Ceară-roșie.

**Brochiu: rubrica: indidem per metathesim: veres kréta: der Rötel, oder Rötelstein.

Marea roșie.

Peatră roșie.

\subsection{Albastru}

Definiția culorii din DEX urmează același tipar ca în cazul culorilor descrise mai sus: adj. Care are culoarea cerului senin; subst. Una din culorile fundamentale ale spectrului luminii, situată între verde și indigo (pe lângă descrierea științifică este indicată şi poziţia în cadrul acestuia prin raportare la alte două culori); culoarea descrisă mai sus (parafrază care face referire la definiția adjectivală - culoarea cerului senin); albăstreală, albăstrime (descrierea culorii prin sinonime).

Pentru nuanțele de albastru care apar în LB (violaceu, vâlced, vânăt - traduse, de altfel, în maghiar tot prin kék), se regăsesc următoarele definiții în DEX:

Vânăt $a d j$. De culoare albastru-închis (cu reflexe violete). subst. Culoare vânătă.

Violaceu $a d j$. Care bate în violet, care are nuanțe de violet. subst. Culoare care are aceste nuanțe.

Pentru vâlced găsim doar verbul derivat, $a$ vâlcezi, cu definiția (refl. și tranz.) A (se) învineți.

Albastrul apare în LB în următoarele situații:

Adjectiv:

Albastru p. e., albastru din vânăt: candicans e ceruleo: fejéres kék, világoskék: hellblau, lichtblau.

Merău: caesius, caeruleus, caelestinus: kék, világoskék, égszínü: himmelblau. - p.e., ochii merii: oculi caesii: kék szemek: blaue Augen.

Nălbastru - Albastru.

g: violaceus: violaszínü: veilchenblau.2.: setétpiros (nigricans e rubro, dunkelrot) [** Năsădit indică de fapt două culori: violaceu, respectiv roșu închis: nigricans e rubro: setétpiros: dunkelrot, vezi și la roșu].

Vânăt: caerulans, lividus: kék: blau. // — cam vânăt: subcaeruleus: kékes: blaulich. // — vânăt deșchis: candicans e caeruleo: világoskék, égszínü: hellblau, himmelblau. // vânăt închis: fuscus e caeruleo: setétkék: dunkelblau. // - cu ochii vânăţi: caeruleis oculis: kékszemü: blauäugig. // De la venetus, i. e. în fața apei.

Vioală - în faţa vioalei: adj. violaceus: violaszínủ: Veilchenfarb, Veilchenblau

Vinețiu: subcaeruleum: kéke[s]: blaulich.

Vâlced: lividus, sugillatus: kék a veréstöl: blau vom Schlagen.

\section{Substantiv:}

Vânătare: vibex, livor, suggillatio: kékség, testnek ütés miatt megkékülése: die Strieme, Schwiele, der blaue Fleck vom Schlagen. 
Vâlcezeală: vibex, livor, suggillatio: kék nyoma a ver[é]snek: die Strieme, Schwiele, der blaue Fleck vom Schlagen.

Vinețeală: caeruleum: kék festék: die Blaue.

Verb:

Învinețesc - I. verb. act. ceva, i. e. fac sau văpsesc vânăt: livido, caeruleum reddo: megkékíteni: blau machen, blau färben. II. neutr. liveo, livesco: kékülni: blau werden.

Vâlcezesc I. verb. act. pre cineva, adecă îl fac vânăt prin bătaie: suggillo: verés által megkékíteni: blau schlagen Jemanden. II. neutr. sau rec. mă vâlcezesc, adecă mă fac vânăt de bătaie: suggillor, liveo: veréstől megkékülni: blau werden vom Schlagen

Vinețesc - I. verb. act. i. e. fac sau văpsesc vânăt: livido, caeruleum reddo: kékíteni: blau machen, blau färben. II. verb. neutr. i. e. mă fac vânăt: liveo, livesco: kékülni: blau werden.

Albastru în combinații lexicale:

In denumirile de plante:

Burete-vânăt: Agaricus violaceus, Linn.: kékhátú gomba: der Veilenblaue, Blätterschwamm.

Crin-vânăt: Iris, Linn. vel gladiolus: kékliliom: die blaue Lilie, oder Schwertlilie.

Lilie vânătă: Iris germanica: kékliliom: die blaue Lilie, Schwertlilie.

Scai vănăt: Eryngium planum, Linn.: kéktövis: die blaue Diestel.

Stângen vânăt: Iris germanica, Linn.: kékliliom: die blaue Lilie, Schwertlilie.

Vinețea - o plantă subst.: Centaurea cyanus, Linn.: kék búzavirág, imola: die Kornblume.

Alte combinații:

Peatră vânătă - Peatra boilor.

\subsection{Galben}

Adjectivul cromatic galben are următoarea definiție în DEX: adj. De culoarea aurului, a lămâii, etc. (se recurge la definirea prin referenți). Ca substantiv, se regăsește o definiție științifică care face referire la spectrul solar, completat prin poziţionarea culorii între alte culori ale spectrului: Una dintre culorile fundamentale ale spectrului solar, situată între portocaliu și verde.

Variante ale culorii galben regăsite în LB: aur, plăviț, în fața șofranului. Mai jos se vor reda definițiile pentru aceste intrări din DEX:

Plăviț: (despre părul sau lâna animalelor) de culoare alb-gălbuie; (despre oameni) $\mathrm{Cu}$ pielea albă și cu părul blond; (despre părul oamenilor) blond, plăviu.

Şofran/Şofrăniu: de culoare galbenă; substantivul şofran denotă planta, respectiv substanța colorantă, de culoare galbenă, extrasă din această plantă

Culoarea galbenă în LB este prezentă în următoarele forme:

Adjectiv:

Aur, ca auru sau în fața aurului, adj.: aureus, fulvus, aurei coloris: aranyszínü: goldfarbig, wie Gold. 
Gălbinicios 1) gălbiniu: fulvaster, subflavus, helvolus: sárgás: gelblich, etwas gelb. 2) la față, adecă perit: pallens, pallidulus: halavány, sápadt: blaß, bleich. 3) care are gălbinare: ictericus, aurugineus, arquaticus: sárga betegségben lévő: gelbsüchtig.

Gălbiniu: subflavus, fulvaster: sárgás: gelblich, etwas gelb.

Galbin 1) la văspseală: galbinus, galbeus, fulvus, flavus, gilbus, gelvus: sárga: gelb. 2) la față, adecă perit, fără fați: pallens, pallidus: sárga, sapadt, halavány: blaß, bleich

Plăviț i. e. galbin: flavus: sárga, sárga szabású: blond.

Șofran, în fața șofranului: crocatus: sáfrányszínü: safrangelb.

Substantiv:

Gălbineață 1) flavedo, color clavus: sárgaság, sárga szín: die gelbe Farbe. 2) la față: pallor: halaványság: die Bläße, Bleichheit.

Gălbinare: sárga festék (luteum, pigmentum flavum).

Verb:

Gălbinesc I. act. ceva, adecă fac, văpsesc galbin: flavo, colore pingo: sárgán festeni: gelb machen, oder färben. II. neutr. vel rec. galbinesc sau mă gălbinesc, adecă mă fac galbin: flavesco: sárgulni: gelb werden.

Galben în combinații lexicale:

In comparații:

Galbin ca ceara: cerinus: sárga mint a viasz: wachsgelb.

In denumiri de plante:

Floare de vioală, adecă vioală-galbenă: Cheiranthus cheiri, Linn.: sárga viola: die gelbe Viole, Lackviole, die gelbe Levkoje, der goldene Lack, das gelbe Veilchen.

Floare-niprală-galbină: Lupinus luteus, Linn.: sárga fürtösviola: die Lupine, Feigbohne.

Burete-galben: Agaricus cantharellus vel deliciosus, Linn.: rókagomba, sárga vargánya: der Pfifferling, der Reitzger, die Ritsche.

Gălbinare, o plantă: Serratula tinctoria, Linn.: [z]soltina: die Scharte, das Schartenkraut.

Ghimberiu-galbin: Curcuma longa: Linn.: sárga gyömbér: die Gurkumei, oder der gelbe Ingber.

Lemn-galbin, macriș-de-spin: Berberis vulgaris, Linn.: sóskafa, borbalya, leánysom: der Sauerrach, der gemeine Sauerdorn, Berberisstrauch.

Lilie galbină: Iris pseudacorus, Linn.: sárgaliliom: die Wasserlilie, oder gelbe Lilie.

Plumoană galbină: Nymphaea lutea, Linn.: sárga vízitök: die gelbe Seerose.

Pur - o iarbă sau plantă: i.e. luminea sau luminărea, căptălană galbină: ökörfarkfükóró (Verbascum thapsus).

Scânteuță galbină: Ranunculus ficaria vel Chelidonium minus, Linn.: aranny[a]l versengő: das kleine Schellkraut, Scharbockskraut, Feigwarzenkraut.

Stângen galbin: Iris pseudacorus, Linn.: sárgaliliom: die Wasserlilie, gelbe Lilie.

Trandafir galbin: Rosa eglanteria: sárga rózsa: die gelbe Rose.

Vioală galbină: Cheiranthus [cheiri], Linn.: sárga viola: die Levkoje, der gelbe Veigel, der Goldlack.

\section{Alte combinații:}

Galbin: aureus: arany: der Dukaten.

Gălbior, gălbinaș. dim. 
Gălbinare, o boală: icterus, aurugo, morbus arquatus, morbus regius: sárgaság, sárga betegség: die Gelbsucht. - cu gălbinare sau care are gălbinare: ictericus, arquaticus: sárgaságban lévő: gelbsüchtig.

Gălbinuș de ou: vitellas, luteum: tojásszék, sárgája a tojásnak: der Dotter, Eidotter.

Miare de trestie galbină: saccharum crystalinum, vulgo: saccharum candum: sárga nádméz: der Zuckerkand, oder Zuckerkandel, Kandelzucker.

\subsection{Verde}

Definiţia culorii verzi în DEX nu diferă de restul culorilor. Astfel, ca adj. este definit ca ceva având culoarea frunzelor, a ierbii sau, în general, a vegetaţiei proaspete de vară. Ca subst. se respectă abordarea științifică, fiind definit ca una dintre culorile fundamentale ale spectrului solar, situată între galben și albastru, care este aceea a frunzelor, a ierbii fragede etc.

În comparație cu celelalte culori studiate, se observă că, sub aspect lexical, paradigma culorii verde este relativ săracă. Acesta se explică, în parte, prin caracterul comun pe care această culoare îl are la nivel referențial (pare a fi la îndemână), dar și prin inconsistența sa compozițională, fiind foarte apropiată de alte tonalități, de ex. albastru, gri, galben (Popescu 2014, p. 265).

\section{Adjectiv:}

Azim 2) verde, crud: viridis, crudus, recens: nyers, zöld: grün, roh.

Înverzit, $f$. -tă; $p l$. -ţi, $f$. -e. Înverzit, -tă. $i$. $e$. verde, adj.: viridis: zöld: grün. - A Lat. viridis.

[Iarbă] de iarbă sau în fața ierbei: gramineus.

[Mare] în fața mării, adj.: coloris marini, veneti: tengerszínü: meergrün.

Verde. f. Verde. subst. I., adj. unius terminationis: 1) după față: viridis: zöld: grün. cam verde: subviridis: zöldellö: grünlich.

\section{Substantiv:}

Înverzire $f$. Înverzire. subst.: viriditas: zöldülés: das Grünen.

Verzime $f ., p l$. -mi. Verzime. subst. v. Verdeaţă.

Verzi. Verzi. $p l$. adecă verdeţuri. v. Verdeaţă.

\section{Verb:}

Înverzesc I. act. ceva, $i$. e. fac verde: virido: megzöldíteni: grün machen. II. neutr.: vireo, viresco, viridor: zöldülni, zöldelleni: grünen, grün werden.

Verzesc I. act. ceva: virido: zöldíteni: grün machen. II. neutr.: vireo, viridor, viresco: zöldülni, zöldelleni: grün werden.

Adverb:

Verde 1) viride: zöldön: grün. 2) chiar, apriat, limpede, românește: aperte, clare, plane, distincte: világosan, kereken, magyarán: deutlich, ausdrücklich. p.e. ţi-am spus verde: aperte dixi tibi: magyarán megmondottam néked: ich habe es dir ausdrücklich gesagt. 


\section{Culorile derivate din Lexiconul de la Buda}

În afara culorilor de bază, prezentate în detaliu, în materialul Lexiconului de la Buda se regăsesc câteva nuanțe ale unor culori mai puțin productive, care, în majoritatea cazurilor, sunt exprimate prin comparații sau prin construcții metaforice.

\section{Brun, maro}

Bârnaciu negriu: badius, spadix, subfuscus: barna: braun, schwarzbraun

Căpriu, se zice despre ochi: nigricans egilvo: fekete-sárga: schwarzgelb.

Nuc, în fața nucului: coloris nucei: diófaszínú: nussfarben.

Oacheș, bârnaciu, negriu la față: badius, spadix, subfuscus: barnaképủ: braun, braunt.

\section{Gri și variante}

Brumat, sur, în fața brumei: canus, colore murino: deres, szürke: grau.

Cenușă, în fața cenușei: adj. cineraceus, coloris cinerei: hamuszínű: aschfarbig, oder aschenfarbig.

Fier, fața fierului: ferrugo: vasszín: die Eisenfarbe. În fața fierului: ferrugineus: vas színü: eisenfärbig.

Murg, cal: nigricans e glauco: setétszürke: schwarzgrau, eisenschimmel.

Pei, adecă cal: badius, spadix, gilvus: pejló: ein blasses Pferd, das Blassl3.

Porumb, în fața porumbului: columbinus: galambszínű: taubenfärbig.

Sein: glaucus: szürke: grau4.

Șoarece, în fața șoarecelui: colore murino: egérszínü: mausfarbig.

Ştiucă, în fața știucii: caeruleus, ferrugineus: csuka színü: hechtgrau.

\section{Alte culori}

Cadavros, cu color [...] de mortăciune: cadaverosus: [...] holt színü: totenfärbig.

Olei, ca oleiul sau în fața oleiului, adj.: oleaceus: mint az olaj, vagy olajszínü: ölig, dem Öl ähnlich, ölfarbig.

Lucrarea și-a propus o prezentare a cromonimelor extrase din Lexiconul de la Buda, în perspectiva unei analize mai ample a termenilor cromatici prezenți. Obiectivul principal al studiului constă în identificarea termenilor cromatici referitori la culorile de bază regăsite în corpusul LB, respectiv în prezentarea sistemului de culori specific limbii române din perioada redactării Lexiconului de la Buda. În acest sens, sub aspect cantitativ, se remarcă faptul că paradigmele lexicale analizate în această lucrare, referitoare la culorile de bază, sunt relativ bogate ca număr de constituenți și variate ca tipuri de nuanțe cromatice. Materialul vast obli-

\footnotetext{
${ }^{3}$ Pei în definiția MDA: 1. Cenușiu. 2. Murg

${ }^{4}$ Sein în definițiile unor dicționare moderne: DEX: (despre lână, blană) De culoare cenușie-roșcată. 2. (despre oi) Cu lâna cenușie-roșcată; MDA: 1 a (Pop; d. lână, blană, păr sau obiecte confecționate din astfel de materiale) De culoare naturală presărat cu negru sau cu maro. 2 a (Pex; d. animale, în special d. oi) Care are lâna, părul, pielea seină (1). 3-4 a (Reg; pan; d. păr, barbă, mustăți; pex; d. oameni) Cărunt (1-2). 5 sf Varietate de struguri cu bobul de culoare albă-cenușie sau neagră-vineție
} 
gă la continuarea prelucrării bazei lexicale oferite de LB, datele prezentate necesitând o abordare și o valorificare profundă a acestora.

\section{ABREVIERI BIBLOGRAFICE. SIGLE}

DEX = Dicționarul explicativ al limbii române, București, Editura Univers Enciclopedic, 2016.

MDA = Micul dicționar academic. Ediția a II-a, București, Editura Univers Enciclopedic, 2010.

$\mathrm{LB}=$ Lexiconul de la Buda (1825). Ediție electronică realizată de Maria Aldea, Daniel-Corneliu Leucuța, Lilla Marta Vremir, Vasilica Eugenia Cristea, Adrian Aurel Podaru. Coordonator Maria Aldea, Cluj-Napoca, 2013. https://www.bcucluj.ro/lexiconuldelabuda/site/login.php

Baltă = Silvia Nicoleta Baltă, Despre culori în câteva dicționare românești. Perspectivă istorică și comparativă. https://www.philippide.ro/cultura_2010/9\%20BALTA\%20Silvia\%20final.pdf

Bădescu = Ilona Bădescu, Cromonime animaliere. Termeni care denumesc culori de oi în graiurile oltenești (I), în „Analele Universității din Craiova”. Seria Științe filologice, p. 244-249. https://www.ceeol.com/search/article-detail?id=746914

Chirilă 2019 = Arina Chirilă, Denumirile indirecte de culori: aspecte metodologice, în Ofelia Ichim (coord.), 1918-2018: Limba şi cultura română - structuri fundamentale ale identităţii naţionale: evaluări, perspective, București, Editura Tracus Arte, 2019, p. 57-66. O sută de ani de cartografie lingvistică românească (philippide.ro)

Codreanu, Stanțieru 2017 = Aurelia Codreanu, Svetlana Stanțieru, Nume de culori - nume de plante, în Tradiţie şi inovare în cercetarea ştiinţifică. Colloquia Professorum, ediţia a 6-a, dedicată Anului profesorului Nicolae Filip: 29 septembrie 2016, vol. I, 2017, p. 25-36. 25-36_0.pdf (idsi.md)

Gheorghiu 1968 = Domnica Gheorghiu, În legătură cu terminologia culorilor din limba română, în „Limba română”, XVII, 1968, nr. 1, p. 39-49. http://dspace.bcu-iasi.ro/handle/123456789/3006

Moroianu 2011 = Cristian Moroianu, Originea și evoluția numelor de culori. Dublete etimologice „,cromatice”. În I. Nedelcu, A. Nicolae, A. Toma, R. Zafiu (eds.), Studii de lingvistică. Omagiu doamnei profesoare Angela Bidu-Vrănceanu, București, Editura Universităţii din București. p. 223-231.

Popescu 2014 = Mihaela Popescu, Culori şi nume de culori în latină şi în limbile romanice. Privire sintetică, în Studia linguistica et philologica in honorem Prof. univ. dr. Michaela Livescu, Craiova, Universitaria Publishing House, 2014, p. 255-269.

Radu-Golea 2011 = Cristina Radu-Golea, Cromatica și semnificațile ei în cultura românească, în „Studii de ştiință și cultură”, VII, 2011, nr. 3. p. 151-162. https://www.ceeol.com/search/articledetail?id=27140

Stanțieru, Bîrsanu 2015 = Svetlana Stanțieru, Aurelia Bîrsanu, Termeni cromatici derivați de la nume de realii. Tradiţie şi inovare în cercetarea ştiinţifică, p. 37-44. http://dspace.usarb.md:8080/ xmlui/bitstream/handle/123456789/1437/Stantieru_Termeni.PDF?sequence=6\&isAllowed=y

https://www.academia.edu/34715280/Originea_\%C8\%99i_evolu\%C8\%9Bia_numelor_de_culori_Du blete_etimologice_cromatice_docx

\section{CHERRY-LIKE. COLOUR NAMES IN THE LEXICON OF BUDA (1825)}

(Abstract)

The study aims to present the chromonyms extracted from the Lexicon of Buda, in the perspective of a more extensive analysis of the chromatic terms present in the dictionary. In this respect, from a quantitative point of view, it is noted that the lexical paradigms analyzed in this work, regarding the 
basic colours, are relatively rich in number of constituents and varied in types of chromatic shades. The data presented constitutes a continuous lexiological challenge, requiring a profound approach and capitalization of them.

Cuvinte cheie: Lexiconul de la Buda, cromonime, culori de bază, combinații lexicale, construcții metaforice.

Keywords: Lexicon of Buda, chromonyms, basic colors, lexical combinations, metaphorical constructions.

Institutul de Lingvistică și Istorie Literară „Sextil Pușcariu” al Academiei Române

Cluj-Napoca, str. E. Racoviță, 21 vremirmarta@gmail.com 